\title{
Welcoming Address by SHIN Jang-bum, President of KOICA
}

At Hotel Lotte, Seoul, Korea On the 7th of March, 2007

\section{신 장 범 / KOICA 총재}

Vice Minister of Foreign Affairs and Trade, Mr. Cho Joong-pyo,

Professor Jeffrey Sachs,

Distinguished guests,

and Ladies and Gentlemen,

It is my great honor and pleasure to welcome you to the opening ceremony of the "ODA international conference" organized by KOICA and hosted by the Ministry of Foreign Affairs and Trade on the theme of "searching for effective measures to achieve the MDGs."

The challenge of achieving the MDGs

Today, one out of every six people in the world lives in extreme poverty. In 2000, all member states of the United Nations endorsed the Millennium Development Goals. These goals call for the decisive reduction of extreme poverty, hunger and disease by the year 2015.

The Millennium Development Goals hold great significance as they are time-bound, measurable, and internationally agreed upon. However, these goals are the mid-term goals to the complete end of extreme poverty by the year 2025 .

There are many challenges facing these ambitious goals, and some are skeptical about their success. Nevertheless, the international society is continuing to make great efforts to achieve these goals. 
I believe ending poverty is possible with the strong commitment of the donor countries to keep their promise, and of developing countries to fulfill their responsibility to develop their countries.

\section{Korea' s commitments}

The most valuable asset Korea has as a donor country is its experience of transforming from a poverty-stricken country into one of the world's most economically developed in just 50 years. Korea's development experience provides the international donor community with examples of effective strategies to eradicate poverty. Many developing countries have expressed their desire to learn from Korea's development experience.

Although Korea's ODA is at a modest level, we will continue to help our partner countries overcome extreme poverty. We will participate in the international efforts to achieve the MDGs, and will fulfill our role and responsibility in the international community which is commensurate with our global strength.

KOICA is developing an aid strategy based on Korea's past experience in order to maximize the effectiveness of its limited aid and to contribute to the achievement of the MDGs. Through "Country Programming", KOICA is also assisting partner countries based on their needs and their development situation.

\section{Closing remarks}

Distinguished guests,

I would like to thank all the participants from the public and private sector for joining us today. I hope this conference will be a valuable opportunity to enhance the Korean public's awareness of this pressing global issue, and contribute to future discussions on the achievement of the MDGs.

Thank you. 